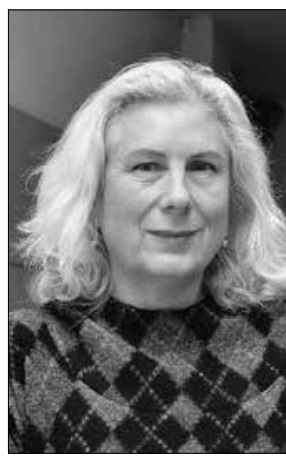

https://doi.org/10.24101/logos.2018.58

Gauta 20180810

INGRIDA BARANAUSKIENE்

Klaipėdos universitetas, Lietuva

Klaipėda University, Lithuania

\title{
M. BACHTINO IDĖJOS INTERAKCINIO ETNOGRAFINIO TYRIMO ARCHITEKTONIKAI ${ }^{*}$

\author{
Bakhtin's Ideas for Architectonics \\ of the Interactive Ethnographic Research
}

SUMMARY

The article deals with M. Bakhtin's scholarly works on the methodology of interactional ethnography. The thematic analysis of three books by M. Bakhtin locates five themes of interactional ethnography: the meaning and responsibility of science, the environment and its influence on cognition, participatory philosophy, the significance of language on one's cognition of reality, the author's attitude toward the hero. Undoubtedly, the methodology of interactional ethnography was and is investigated by many others; however, $\mathrm{M}$. Bachtin's work on the architectonics of investigation, introspection, centres of value, the dependence of values on contexts, the influence of environments on cognition of a phenomenon, the merging of the unity of man's culture with other areas, involved participation, unavoidability of subjectivity, the attitude toward ethical norms etc. is accepted and used by scientists who acknowledge the interactional ethnography approach. M. Bakhtin can be considered as a scientist who was a century ahead of his time and as an influence on the contemporary world through several scientific areas, including interactional ethnography.

\section{SANTRAUKA}

Straipsnyje pateikiamas tyrimas, kuriuo atskleidžiama M. Bachtino darbų daroma įtaka interakcinės etnografijos metodologijai. Atlikta trijų Bachtino knygų teminė analizė išryškino penkias temas, kurios siejasi su interakcine etnografija: mokslo prasmè ir atsakomybė; aplinka ir jos įtaka pažinimui; dalyvavimo filosofija; kalbos reikšmė tikrovės pažinimui; autoriaus požiūris į herojų. Be abejonės, interakcinės etnografijos metodologiją formavo ir formuoja daugelis mokslininkų, tačiau Bachtino mokymas apie tyrimo architekto-

* Mokslinis tyrimas finansuojamas Europos socialinio fondo lěšomis pagal priemonès Nr. 09.3.3-LMTK712 veiklą „Mokslininkų kvalifikacijos tobulinimas vykdant aukšto lygio MTEP projektus“.

RAKTAŽODŽIAI: Bachtinas, interakcinė etnografinė perspektyva, architektonika.

KEY WORDS: Bachtin, interactional ethnographic perspective, architectonics. 
niką, introspekciją, vertybinius centrus, vertybių priklausymą nuo kontekstų, aplinkų įtaką reiškinio pažinimui, žmogaus kultūros vienovès susiliejimą su kitomis sritimis, dalyvavimą įsijaučiant, subjektyvumo neišvengiamumą, požiūris ị etines normas ir kt. yra pripažintas ir juo remiasi interakcinès etnografijos prieigą pripažįstantys mokslininkai. Bachtiną galima vertinti kaip mokslininką, šimtmečiu pralenkusị laiką ir darantį įtaką šiuolaikiniam pasauliui ne per vieną mokslo sritį, tarp jų ir per interakcinę etnografiją.

\section{IVADAS}

Visuomenei diskutuojant apie robotonikos ir dirbtinio intelekto perspektyvas, kultūrologai, politologai, psichologai, edukologai, sociologai, biomedicinos mokslų atstovai ieško naujų idèju , kaip suprasti vykstančius pokyčius, kokias rasti tyrimu prieigas, kurios leistų suprasti, kodèl pasaulis, padaręs sparčią, net galima teigti, revoliucinę pažangą technologijose, žmonių santykiuose nepašalina ittampos lauku, kurie daugeliu atveju tęsiasi nuo antikos laikų. Šiame kontekste socialiniai mokslai, taip pat ir kitos mokslo sritys, pozityvistini požiūri keičia postpozityvistiniu ${ }^{1}$. Interakcinę etnografiją kaip tik galima įvardinti kaip prieiga, kuri i socialinę tikrovę žvelgia iš postpozityvistiniu pozicijų. Interakcinès etnografijos ideologu laikomas Jamesas P. Spradley, parašęs ar redagavęs ne vieną dešimti knygu, kuriose ne tik ieško atsakymų, kaip pažinti tikrovę būnant kartu su žmonèmis, bet ir pateikia konkrečias metodikas ir metodus ${ }^{2}$. Jamesas P. Spradley (kartu su Davidu W. McCurdy) išplètojo interakcinę etnografiją tyrinėdami visuomenès kultūrą ${ }^{3}$. Kita žymi JAV mokslininkė Judith L. Green interakcinę etnografinę prieigą naudoja tyrinèdama mokyklinės klasès kultūrą ${ }^{4}$, itin daug dèmesio kreipdama $i$ kalbą ne tik kaip $i$ informacijos, bet ir i gelminių reiškiniu suvokimo šaltinį ${ }^{5}$. Maria Lucia Castanheira kartu su Teresa Crawford, Carol N. Di- xon, Judith L. Green analizuoja raštingumą kaip socialiai konstruojamą reiškinį, kuris priklauso nuo situacijos ir iš naujo apibrèžiamas skirtingose socialinèse grupėse, kaip kad skaitymo grupėse, šeimose, klasėse, mokyklose, bendruomenėse ir profesionalu grupėse (pvz., pedagogu, teisininku, administratorių ir santechni$\mathrm{ku})^{6}$. Galima teigti, kad interakcinès etnografijos mokykla, kaip reiškinys, aktyviai keičia pozityvistinį mąstymą ir dalyvauja visuomeniniame gyvenime.

Mokslininkai, savo metodologijoje taikantys interakcinę etnografija, dažnai remiasi Michailo Bachtino idejjomis. Lietuvoje M. Bachtinas žinomas kaip Dostojevskio tyrinètojas, filologas ir filosofas. Garsiausi jo mokymai mūsu šalyje siejami su dialogo, karnavalo filosofija. Todèl natūraliai kyla klausimai: kaip Bachtino idejos siejasi su interakcinès etnografijos prieiga? Kuo jo kultūrologinès koncepcijos gali būti naudingos interakcinès etnografijos tyrimui? Kodèl sovietinis mokslininkas yra toks populiarus pasaulyje tarp interakcinès etnografijos metodologų? Šie ir į juos panašūs klausimai ir atspindi straipsnio problemą.

Norint atsakyti i minètus klausimus, buvo remiamasi trimis Bachtino knygomis $^{7}$. Knygu pasirinkimas ivardintinas kaip "patogioji imtis“. Pirmiausia buvo atliekama pirminè teksto analizè renkant citatas ar net pastraipas, kurios 
turi nors koki ryši su interakcinės etnografijos prieiga.

Kitas teksto analizès etapas buvo siejamas su analizès atsvaros taško paieška apskritai. Kartu su Bachtino knygu pirmine analize buvo gilinamas interakcinès etnografijos suvokimas: studijuojami J. Spradley ${ }^{8}$ darbai bei Audros Skukauskaitès mokslinis straipsnis ${ }^{9}$. Kaip jau buvo minèta, M. Spradley, etnosemantika grịsdamas etnografinę prieiga sukūrè ir praktiškai pritaikè 12 žingsnių strategiją ${ }^{10}$. A. Skukauskaitè savo straipsnyje išskyrè keturis esminius interakcinès etnografijos ideją nusakančius principus $^{11}$. Buvo diskutuojama su interakcinès etnografijos ekspertais siekiant išsiaiškinti, kuriuo iš minètų autorių remtis analizuojant Bachtino idejjas etnografinio tyrimo architektonikai ${ }^{12}$. O gal ieškoti kitų strategijų? Termino „,architektonika“ pasirinkimas (šis terminas yra labai dažnas Bachtino darbuose) lyg ir nurodo, kad apsisprendžiama labiau gilintis i interakcinio etnografinio tyrimo sandara, jo visumos ir dalių santykí. Tačiau pagal interakcinès etnografijos suvokima, $\mathfrak{i}$ terminą , architektonika“ telpa kur kas daugiau negu struktūra, jos dalių santykis. Architektonika suvokiama kaip tyrimo visuma, su jos dvasia, drama ar komedija, džiaugsmais ar sunkumais, laimèjimais ar ydomis. Architektonika siejama ne tik su "pastatu“, bet ir su jo projektuotojais, statytojais, gyventojais, jų likimais. Toks susiformavęs požiūris turëjo itakos sprendimui, kad bus atliekama neformalizuota analizè, kurioje nebus remiamasi nei klasikiniais Spradley žingsniais, nei A. Skukauskaitès atskleistais principais, nei kitais autoriais, o pasitelkiama interakcinès etnografijos, kaip tyrimų krypties, samprata apskritai.

Trečiasis tyrimo etapas skirtas Bachtino idejų sisteminimui ir analizei. Po pirminès Bachtino darbų analizès jo idèjos buvo grupuojamos pagal temas. Vèliau temos buvo apibendrinamos, sintetinamos, ivvardijamos ir revizuojamos. Išryškëjo penkios temos, kurios siejasi su IE ${ }^{13}$ : mokslo prasmè ir atsakomybé; aplinka ir jos ittaka pažinimui; dalyvavimo filosofija; kalbos reikšmè tikrovès pažinimui; autoriaus požiūris ì herojų. Šiame straipsnyje analizuojamos tik pirmosios trys temos.

Ketvirtas tyrimo etapas orientuotas $i$ naujų žinių sintetinima, kūrimą ir perkèlima, kartu atsakant i straipsnio problemą apibrèžiančius klausimus.

\section{MOKSLO ATSAKOMYBE் IR PRASME்}

Atlikus Bachtino darbų ${ }^{14}$ IE kontekste tyrima, pirmoji tema siejama su mokslo prasme ir atsakomybe. Bachtinas savo darbuose ieško, analizuoja ir atskleidžia architektonikos prasmę, ypač gilinasi i vidinès prasmès paieškas, akcentuoja tik nepaviršutiniško tyrimo prasmę pažinimui, akcentuoja vertybiu, kaip sistemos, svarba, iškelia abejonę kaip vertybę, ver- tybiu kaitos procesus, tiesiogiai transliuoja ideją apie mokslo ir mokslininko atsakomybę.

Rašydamas apie architektonikos prasmę, Bachtinas iškelia žmogu. Viskas sukasi apie konkretų asmenį: "Architektonika - kaip vizualiai būtinas, neatsitiktinis konkrečių vienatinių dalių bei aspektų išdèstymas ir ryšys išbaigtoje vi- 
sumoje - imanoma tik aplink konkretu žmogu - herojų. "15 IE tyrinètojui ši mokslininko žinia yra labai svarbi. Konkretus žmogus konkrečioje situacijoje pradeda ir baigia IE tyrimo sumanymą. Kaip teigia Bachtinas, „mintis, problema, tema negali būti architektonikos pagrindas ${ }^{\prime 16}$. Mintis be žmogaus, tyrimo dalyvio gali likti tik tavo mintimi, tavo problema ir tavo tema. Perfrazuojant Bachtiną galima teigti, kad siekdamas visavertès minties, konceptualumo, tyrèjas turi nedvejodamas sekti paskui tyrimo dalyvị jam nenurodinèdamas, nepatardamas ir tik taip konstruodamas savo tyrimą. Tyrimo architektonika, anot mokslininko, pasižymi issigyvenimu: „heroju ir objektu matymu iš vidaus ${ }^{\prime 17}$ - pamatyti fenomeną iš vidaus būnant išoriniu tyrimo dalyviu - kiekvieno IE tyrèjo siekis. Perfrazuojant Bachtina, IE labai svarbus vidinès žiūros taškas ${ }^{18}$ architektoniniame lauke. Tik žiūrint i tyrimą iš šių poziciju „tampa apskritai imanoma aprépti visą architektoniką - vertybinę, laikinę, erdvinę ir prasminę - vieningu, lygiai įtvirtinančiu aktyvumu “19. Gilinantis į šią citatą galima teigti, kad išryškèja tyrèjo, kaip tyrimo dalyvio, dualizmas: viena, jis tarsi pasyviai seka savo tyrimo dalyvi, antra, aktyviai gilindamasis i i vertybines, laiko, erdvès ir prasmès situacijas iš pasyvaus dalyvio tampa aktyviu - tai reiškia, kad taip tyrejjas konstruoja tyrima, kuria tyrimo architektoniką. Tik taip tyrẻjas gali pamatyti visapusišką ir ịrodymais gristą situaciją: „Mes matome veikèją idejoje ir per idejją o idèją matome jame ir per ji.." ${ }^{20}$ Tikètina, kad IE tyrimo architektonika perèmé dar vieną labai esminę mintį: rašydamas apie Dostojevskio kūrybą mokslininkas teigia, kad „Dosto- jevskiui svarbu, ne kas jo veikèjas yra pasaulyje, bet pirmiausia, kuo veikejui yra pasaulis ir kuo jis pats sau yra“21. Kitaip sakant, neužtenka suvokti, kas buvo pasakyta, bet reikia issigilinti i tai, kaip buvo priimta, kaip tai pakeitè dalyvius ir pasauli.

Architektonika be vidinès prasmès paieškų nebūtų visaverté, tokia visuma būtų tik mechaninè22. Rašydamas apie Dostojevski, Bachtinas teigia, jog jo stiprybè buvo tai, kad jis rèmèsi „,introspekcija $^{23}$ ir kitu žmoniu stebejjimu, ir labai geru žmogaus pažinimu iš rusų ir pasaulio literatūros, tai yra rèmèsi vidine ir išorine patirtimi ir todèl igijo objektyvią reikšmę ${ }^{\prime 24}$. Būtent tą pačią prieigą akcentuoja ir straipsnio ìvadinejje dalyje minèti IE mokslininkai. Nuodugniai pažinti tyrimo lauką be išorinių nuostatu, analizuojant, argumentuojant savo matymo logiką. Tik toks kelias, perfrazuojant Bachtina, užtikrins „objektyvią reikšmę ${ }^{\prime 25}$ ir atskleis vidinę prasmę. Klaipedos universitete vykstančioje vasaros mokykloje ${ }^{26}$ prof. Davidas Bloome'as, perpasakodamas Bachtina, pateikè ne vieną pavyzdi, tame tarpe ir apie Newtono dèsnių reikšmingumą. Tai taip pat i̇rodo Bachtino ideju perèmimą IE. Bachtinas teigè, kad „Newtono dèsniai buvo reikšmingi savaime dar prieš juos atrandant Newtonui, tad ne jų atradimas padare juos pirmąkart svarbius, tiesiog šios tiesos nebuvo suvoktos, nebuvo tapusios vienatinio būties ívykio dalimi. O tai labai svarbu, mat del to poelgis, kuriuo jos pažistamos, tampa prasmingas. ${ }^{.27} \mathrm{IE}$ mokslininkai tai pripažįsta kaip reiškinio absoliutą: jis yra visada, bet prasmingas tampa tik tada, kai įsisąmoninamas ir suvokiamas. 
Bachtinas aiškiai apibrèžia vertybių sistemą ir juc reikšmę, ,pasaulio poelgio“28 architektonikai: „,...mokslinés, estetinès, politines (taip pat etinès bei socialinès) ir pagaliau religinés vertybès. Visos erdvès bei laiko ir turinio bei prasmès vertès ir santykiai tampa reikšmingi per šiuos pagrindinius emocinius - valinius aspektus: aš, kitas ir aš - kitam“29. Matydamas vertybes kaip sistema, Bachtinas atskleidžia vertybių priklausymą nuo kontekstų, kaip jis teigia, „erdvinių ir laikinių bei emocinių - valinių ryšių “30. Bachtino pateiktas pavyzdys iš Italijos "jai - tèvyne, jam - svetima šalis“" ${ }^{\prime \prime}$, buvo pateiktas ir minètoje vasaros mokykloje. IE perėmė Bachtino idejjas apie „vienatinę objekto vieta, kuri savo ruožtu priklauso nuo vienatinés dalyvaujančio subjekto pozi-


pabrèžia transgredientiškumą kaip būtiną sąlygą ${ }^{33}$.

\section{APLINKA IR JOS ITAKA PAŽINIMUI}

Bachtino filosofijoje aiškiai ir visapusiškai atskleista aplinkos ittaka pažinimui. Tai galètume ivvardinti kaip antrą tema, kurios idejjas sėkmingai perèmè IE metodologai. Studijuojant Bachtino darbus galima izžvelgti aplinkų, turinčių itakos fenomenui, izvairovę: tai ir istorinè, poelgio, kontekstinè, daiktinè, vidinio pasaulio, kultūrinè ir kitos.

Istorinés aplinkos svarbą Bachtinas atskleidžia teigdamas, kad „atplèšiant teigini nuo istorinio tikrovejje vykstančio poelgio veiksmo ir priskiriant prie vienos ar kitos teorinès visumos, iš jo turinio ir prasmès vidaus nebelieka išejimo ì priklausomybę bei tikraji vienatini büties $i v y k i^{\prime \prime 34}$. Perfrazuodami mokslininką galime teigti, kad jeigu atplèšiame turini nuo istorijos, tai tik bandome pakelti save už plaukų ${ }^{35}$. Kita aplinka, daranti itaką pažinimui, yra poelgio aplinka. Anot mokslininko, visada poelgio prasmè slypi poelgio viduje, nes "poelgis iš


aplinkoje. Kita vertus, poelgio aplinka, suvokiama kaip procesas, kaip veiksmas, žodis, mintis, jausmai ${ }^{37}$ : „,aš gyvenu elgdamasis“38. Todèl IE mokslininkai daug dėmesio skiria poelgio pažinimui: kas lèmè poelgi, kaip jis įvyko, koki padarè poveiki, kaip tai pakeitè pasauli? Šie IE mokslininkų klausimai pratęsia Bachtino mokymą. Ne mažiau svarbu, anot Bachtino, kontekstine aplinka. Kontekstinė aplinka "reiške pamąstyti apie visus jo turinius kaip vienu metu vykstančius ir ispèti jų tarpusavio santykius vienu momentu“39. Pateiksime pavyzdi iš negalès tyrimų: negalès kontekste neretai susiduria du vertybiniai centrai (konteksto ir vertybių sąveika) - mamos, auginančios neigalų vaika, ir specialisto. Juos veikia skirtingi kontekstai, nors vertybès gali būti ir tos pačios. Mama nepatenkinta paslaugomis, kaip ir specialistas dèl ịvairių priežasčių - mama. Pirmas koncentras - mamos - yra platesnis, jis apglèbia antraji, specialisto. Gali būti ir dar vadovų (menamas koncentras), valstybès politikos - dar vienas menamas). Minèti koncentrai nulemia, kad specialistas, turèdamas iš esmès panašias vertybes, keičia architektoniką ${ }^{40}$. Kaip galima suprasti iš pateikto pavyzdžio, kontekstai turi ittakos vertybèms, gali jas keisti. Bachtinas herojaus aplin- 
ką sieja ir su daiktiniu pasauliu atskleisdamas jo ittaką poelgiuii ${ }^{41}$. Nepasitenkinimas savimi ar savo galimybiu issisąmonimas, poreikiai ar viltis mokslininko siejamas su vidinio pasaulio įtaka reiškinio pažinimui ${ }^{42}$. Perfrazuojant Bachtina, vidinis dalyvio pasaulis yra vertintinas kaip aplinkos faktorius, darantis didelę itaką poelgiui. Analizuojant aplinkos svarbą pažinimui, „būtina nustatyti ją žmogaus kultūros vienovejje susiejant su kitomis sritimis " ${ }^{\prime 4}$. Būtent tai atsispindi ketvirtame IE principe ${ }^{44}$. Aplinka neatsiejama nuo kitu ,....duomenų šaltinių, teoriju, literatūros, metodu ir perspektyvu ${ }^{\prime \prime 4}$.

\section{DALYVAVIMO FILOSOFIJA}

Bachtinas, kalbėdamas apie dalyvavimą (trečioji tyrimo metu išryškejjusi tema), pirmiausia įvardija reiškinį, kuri pavadinome įsijautimu. IE metodologai tai sieja su išorès ir vidaus dalyviais. Išorès dalyvis, tyrejjas, noredamas suprasti vidaus dalyvi (apie kurį sukasi IE), turi „dalyvaujant išgyventi. Visas teorinis protas ieina i praktini protą ${ }^{\prime 46}$. Bachtinas pripažista, kad „visiškai issigyventi i kita neimanoma ${ }^{\prime 47}$. Tačiau stengtis reikia. Šias pastangas mokslininkas apibrěžia kaip „suinteresuota ir veiklia pozicija“48. Pasyvus aktyvumas nieko neperkuria ir visos „pastangos iš teorinio pažinimo vidaus iveikti pažinimo ir gyvenimo, minties ir vienatinès, konkrečios tikrovès dualizmą yra visiškai beviltiškos " ${ }^{\prime 49}$. Ši mokslininko teiginį IE, ko gero, pripažista kaip vieną esminių. Apskritai tiek Bachtino darbuose, tiek IE metodologijoje issijautimas, ịsigilinimas ị kiekvieną smulkmeną yra vienas svarbiausiu principų. İsijautimas siejamas su daugeliu kitu aspektu, tokių kaip vertybès, aplinka ir kt. Akcentuodamas vidinio žmogaus pasaulio pajautimą (o kaip pajausi neįsijausdamas?), Bachtinas i procesą žiūri iš „vidinius žmones jungiančiojo ìvykio vaizdavimo "50 taško, o tai gerokai praplečia ir dalyvavimo ribas.
Su dalyvavimu siejamas ir kitas išryškëjęs Bachtino principas: subjektyvumo neišvengiamumas. Ko gero, ryškiausiu teiginiu galètų būti šis: „Pasaulis, kuriame aš iš savo vienintelés vietos atsakingai išsižadu savęs, netampa pasauliu, kuriame manęs nèra. ${ }^{\text {51 }}$ Pozityvizmo situacijoje iprastai siekiama objektyvumo, tyrejjas griežtai turi atsiriboti nuo bet kokio subjektyvaus veiksmo, poelgio ar vertinimo. Tyrimo rezultatai turi būti griežtai pamatuojami ir pakartojami. O postpozityvizmu grisstoje IE ieškoma radinių juos paremiant įrodymais. Ir nors, anot Bachtino, „tikroveje vertinimas persmelkia objek$t q^{\prime \prime 52}$, tačiau "mokslinis tyrëjo taktas visada gali išlaikyti ji deramose ribose ${ }^{\prime 53}$. IE metodologai, siekdami "tyrëjo takto", daug dèmesio skiria tyrimo etikai. Tyrimo etika visada svarbiau už radinius.

M. Bachtino darbuose etinés normos taip pat ne mažiau svarbios, tačiau normos suvokimas labai konkretus: ,....kiekviena turininga norma turi igauti specialaus mokslinio teiginio statusa; iki tol ji terra praktine nauda turintis hipotetinis apibendrinimas ${ }^{\prime 25}$. Kita vertus, autorius normą laiko tam tikra „valios kitiems reiškimo forma“ ${ }^{\prime 55}$ ir teigia, kad „teorinis mastymas negali būti varžomas jokiu normu" ${ }^{456}$. Rašydamas apie etiką Bachtinas kaip ydą 
ivardija jos visuotinuma, pritaikymą kiekvienam ${ }^{57}$. Anot autoriaus, „racionalumas paliko prietara, kad tegali būti iš bendrybiu susidedanti absoliuti tiesa, <...> o individuali tiesa yra meniška ir neatsakinga, taigi atmetama, kas individualu. ${ }^{458}$ IE metodologijoje niekada neatmetama tai, kas individualu. Be abejo, ieškoma pasikartojimu, tam tikrų modelių, tačiau individualūs atvejai yra labai svarbūs, IE metodologijoje jie îvairiai ivardijami, pvz., kritiniais, pasakojančiais ir kt.

Tiek dalyvavimo subjektyvumo neišvengiamumas, tiek etinès normos sieja- mos su „atsakingu poelgiu, kuris iveikia bet kokị hipotetiškumą ${ }^{49}$. Atsakomybe nèra nekintamas reiškinys ir "ne pastovus poelgio desniai, <...> o tikras, vienatinis ir nepakartojamas, individualus emocinis valinis pripažinimo faktas " ${ }^{\prime 60}$. IE atsakomybès dinamika taip pat yra ryški. Minètoje vasaros mokykloje ${ }^{61}$, buvo analizuojamas atvejis, kai tyrèjų komanda, atlikdama diskurso analizę, pastebejo mokinès polinki i i savižudybę. Šiuo atveju tyrëjo konfidencialumo atsakomybè dalyvei modifikavosi, ir atvejis buvo aptartas tiek su tyrimo dalyve, tiek su pedagogais, tiek su tèvais.

\section{POST SCRIPTUM}

Bachtino darbų analizè atskleidè glaudų jų ryši su IE metodologija. Šiame straipsnyje analizuotos trys temos mokslo prasmè ir atsakomybe;; aplinka ir jos ittaka pažinimui; dalyvavimo filosofija - irodo Bachtino darbu universalumą ir ittaką IE. Be abejonès, IE metodologiją formavo ir formuoja daugelis mokslininku, tačiau Bachtino mokymas apie tyrimo architektonika, introspekcija vertybinius centrus, vertybiu priklausymą nuo kontekstų, aplinkos įtaką reiškinio pažinimui, žmogaus kultūros vienovès susiliejimą su kitomis sritimis, daly-

\section{Literatūra ir nuorodos}

1 Plg.: „Postpozityvistinių nuostatų besilaikančių sociologu ar politologų nuomonè priešinga: tyrinėtojas negali pažvelgti i socialinę tikrovę iš išorès, jis gali žvelgti i ją tik iš vidaus. Visų pirma jie labiau nei dauguma pozityvistu pabrèžia socialinio ir gamtinio pasaulių skirtumus. Jie akcentuoja, kad socialinę tikrovę žmonès kuria remdamiesi savo idejomis. Žmonių santykiai vavimą îsijaučiant, subjektyvumo neišvengiamuma, požiūris i etines normas ir kt. yra vertinami ir naudojami IE prieigą pripažistančių mokslininkų.

Šiame straipsnyje nenagrinètos išryškejjusios dar dvi temos, kurių viena yra kalbos reikšmė tikrovès pažinimui, tikètina, itin svarbi IE.

Bachtiną galima vertinti kaip mokslininką, šimtmečiu pralenkusị laiką ir daranti įtaką šiuolaikiniam pasauliui ne per vieną mokslo sriti, o ir per interakcinę etnografiją.

priklauso nuo to, ką jie vieni apie kitus mano. Institucijos yra tam tikrų idejjų igyvendinimo rezultatas" (Nakrašas Evaldas. 2010. Pozityvizmo ir postpozityvizmo ginčas socialiniuose moksluose. Politologija 1 57).

2 James P. Spradley, etnosemantika grisdamas etnografinę prieiga, sukūrè ir praktiškai pritaikè 12 žingsnių strategija, kuria remiasi ir šiuo- 
laikiniai tyrejjai, plg.: Spradley James P. 1980. Participant observation. By Holt, Rinerhart and Winston, ISBN 0-03-044501-9.

${ }^{3}$ Spradley James P., McCurdy David W. 1972. The Cultural Experience Ethnography in Complex Society. 1988 reissued by Waveland Press, Inc. ISBN 0-88133-349-2.

${ }^{4}$ Green J. L., \& Harker J. (Eds.). 1988. Multiple perspective analyses of classroom discourse: Methods and issues. Norwood, NJ, Ablex.

${ }^{5}$ Green J. L. \& Wallat C. (Eds.). 1981. Ethnography and language in educational setting. Volume 5 . In Roy O. Freedle (Series Editor), Advances in discourse processes, Norwood: NJ, Ablex.

${ }^{6}$ Plg.: Castanheira Maria Lucia, Crawford Teresa, Dixon Carol N., Green Judith L. Interactional Ethnography: An Approach to Studying the Social Construction of Literate Practices. Linguistics and Education 11(4): 353 - 4002001 by Elsevier Science, Inc. ISSN: 0898-5898.

7 Bachtin M. 2002. Autorius ir herojus: estetikos darbai. Vilnius: Aidai; Bachtin M. 1996. Dostojevskio poetikos problemos. Vilnius: Baltos lankos; Бахтин М. М. 1975. Вопросы хитературы и эстетики: исследования разных лет. Москва: Художественная дитература.

${ }^{8}$ Spradley James P. 1980. Participant observation. By Holt, Rinerhart and Winston, ISBN 0-03044501-9.

9 Skukauskaite Audra. 2017. The Systematic Analyses of Layered Meanings Inscribed in Interview Conversations: an Interactional Ethnographic Perspective and its Conceptual Foundations. ACTA PAEDAGOGICA VILNENSIA 39, 2017, DOI: < https://doi.org/10.15388/ActPaed.2017.39.11466 >

10 Spradley James P. 1980: 38-171.

11 Skukauskaite Audra. 2017.

12 Ką reiškia Architektonika? (gr. architektonike - statybos menas): 1. archit. kokių nors statiniu ar pastato kompozicija; 2. meno kūrinio sandara, jo visumos ir daliu santykis. < http://www.lietuviuzodynas.lt/terminai/Architektonika >

13 Čia ir toliau trumpinys IE reiškia interakcinę etnografiją.

14 Bachtin, М. 2002; Bachtin, М. 1996; Бахтин. 1975.

15 Bachtin. 2002: 88.

16 Bachtin. 2002: 88.

17 Bachtin. 2002: 91.

18 Plg., Bachtin. 2002: 90-91.

19 Ten pat.
${ }^{20}$ Bachtin. 1996: 102, paryškinta autoriaus.

21 Bachtin. 1996: 57.

22 Plg., Bachtin. 2002: 9.

${ }^{23}$ Introspèkcija (lot. introspectio - žiūrèjimas ị vidų), savistaba. < http://www.zodziai.lt/reiksme \&word=Introspekcija\&wid=8747 >

24 Bachtin. 1996: 48.

25 Ten pat.

${ }^{26}$ Klaipedos universiteto $2018 \mathrm{~m}$. vasaros mokyklą organizavo prof. L. Rupšienè. IE ir diskursui analizės mokymui vadovavo profesoriai iš JAV Davidas Bloome'as, Laurie Katzas, dr. Melissa Wilson (Ohajos valstijos universitetas).

27 Bachtin. 2002: 21, paryškinta autoriaus.

28 Plg., ten pat: 63 .

29 Ten pat.

30 Bachtin. 2002: 69.

31 Ten pat: 78 .

32 Bachtin. 2002: 80, paryškinta autoriaus.

33 Plg. Bachtin. 2002: 91.

${ }^{34}$ Bachtin. 2002: 18, paryškinta autoriaus.

$35 \mathrm{Plg}$., ten pat.

36 Bachtin. 2002: 24.

37 Plg. Bachtin. 2002: 245.

38 Ten pat.

39 Bachtin. 1996: 38.

${ }^{40}$ Plg. Bachtin. 2002: 94.

${ }^{41}$ Plg. Bachtin. 2002: 205.

42 Plg. Bachtin. 2002: 252.

43 Bachtin. 2002: 323, paryškinta autoriaus.

44 Skukauskaite Audra. 2017.

45 Ten pat.

46 Bachtin. 2002: 24.

47 Ten pat: 27.

48 Ten pat: 43.

${ }^{4} \mathrm{Plg}$., ten pat, p. 18, paryškinta autoriaus.

50 Plg., Bachtin, M. 1996, p. 19, paryškinta autoriaus.

51 Bachtin, M. 2002, p. 27, paryškinta autoriaus.

52 Bachtin, M. 2002, p. 98, paryškinta autoriaus.

53 Plg., ten pat, p. 357.

54 Plg., ten pat, p. 33.

55 Bachtin, M. 2002, p.35.

56 Ten pat, paryškinta autoriaus.

57 Ten pat.

58 Ten pat., p. 48.

59 Plg., ten pat, p. 39-40.

${ }_{60}$ Plg., ten pat, p. 49.

61 Klaipedos universiteto 2018 metu vasaros mokyklą organizavo prof. L. Rupšienè. IE ir diskurso analizès mokymus vede profesoriai iš JAV David Bloome, Laurie Katz, dr. Melissa Wilson (Ohajos valstijos universitetas). 